\title{
Use of questioning strategy to facilitate students' reading comprehension in Taiwan
}

\author{
Ike Irawati ${ }^{1}$ \\ ${ }^{1}$ Study Program of Management, Economy Faculty, Universitas Krisnadwipayana, \\ Bekasi, Indonesia \\ 1 irawatiike02@gmail.com

\begin{abstract}
This study investigates individual differences arising from strategy instruction, questioning strategy, based on the problems found through miscue analysis. This qualitative study also investigates students' motivation toward the strategy taught. The participants were a college student in Taiwan, consisted of one high-achieving student and one low-achieving student. Both were on the same language proficiency level (level C). They were asked to complete miscue pre and post-test and took eight meetings of tutorials (four meetings for teacher-generated questions and four meetings for student-generated questions). An interview was also conducted to find out their motivation toward the strategy. The instructional materials were taken from an English magazine specially designed for Taiwanese, called Studio Classroom. Results indicated that the strategy did not work well in both students as their motivation interfered their reading performance. This study concludes that the strategy works better in higher motivation student. Since motivation affects students' reading performance, therefore, this study suggests that raising students' motivation in the teaching process is crucial to reach better reading performance.
\end{abstract}

Keywords: miscue analysis; questioning strategy; reading comprehension; motivation

How to cite this paper (in APA style): Irawati, I. (2019). Use of questioning strategy to facilitate students' reading comprehension in Taiwan. Journal on English as a Foreign Language, 9(2), 217-230. doi:http://dx.doi.org/10.23971/jefl.v9i2.1375 
DOI: http://dx.doi.org/10.23971/jefl.v9i2.1375

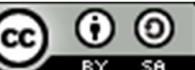

Good readers always apply certain strategies while reading a text. They will see reading as a whole context instead of word-by-word meaning. Goodman, Watson, and Burke (1996) suggested that reading is not only sounding out text, but also constructing meaning (Goodman, Burke, \& Sherman, 1981; Kazemi, Hosseini, \& Kohandani, 2013). This means reading is not just about read the symbols/etters, but also read for its meaning to reach a certain level of understanding or reading comprehension. Readers will be able to comprehend the text if they can "talk" to the text as a text is a means of conveying the author's message and intention towards the readers. Reading is an activity that creates an interaction between readers and writers (Paran, 1996). As Alderson (2000); Klinger, Vaughn, and Boardman (2007) also stated that reading is an interaction between the readers and the texts. There should be a good 'communication' between the readers and the texts. To reach a good interaction and communication between what is printed on the text and readers' understanding, some reading strategies such as summarizing, question generating, skimming, scanning and others (Phillips, 2003) are commonly used. Those strategy instructions need to be taught directly to students to enhance their comprehension.

There are various kinds of reading strategies that may help students to facilitate their problems in comprehending texts. Questioning is among one of those strategies that can be used to improve students' reading comprehension. The importance of questioning as an instructional strategy is widely acknowledged in the literature on teaching and learning (Edwards \& Bowman, 1996). Anisah, Fitriati, and Rukmini (2019) found that students could make more responses when helped by the questioning strategy. Another study also obtained a positive result with a questioning strategy toward students' reading comprehension. El-Koumy (2014) investigated the effectiveness of using questioning strategies within three number of groups (teacher-generated questions, students-generated questions, and teacher-students generated questions). The result showed that teacher-student generated groups scored most significantly higher than in other groups. The difference could also be seen between pretest and posttest though there was also a significant difference in students' score in another two groups. He used a TOEFL reading comprehension test as the pretest and posttest test materials.

Journal on English as a Foreign Language, 9(2), 217-230

Copyright @ 2019 by JEFL, p-ISSN 2088-1657; e-ISSN 2502-6615 
About miscue analysis, it is an instrument that was used to detect students' reading problems in which they were asked to read aloud a text. Miscue analysis not only reveals the readers' proficiency but provides knowledge about the reading process (Goodman, Burke, \& Sherman, 1981). Their reading would be analyzed to mark their reading errors, which would be classified to determine their problems. Some studies tried to examine the relation between miscue analysis and students' reading strategies and performances. Flurkey and $\mathrm{Xu}$ applied miscue research to examine the rate and flexibility with which students read within a text and across text (Long, 1987). This research concerned on how readers struggle with new information and unfamiliar grammatical structures. Another study conducted by Whitmore and Crowell (1994) used miscue analysis to examine the reading strategies used by the third graders. This study tried to find out the reading strategies used by the students while reading a text as shown in their miscue.

Miscue analysis provides a great deal of specific information about a students' reading ability and helps the teacher to plan reading programs and instructional strategies. Basically, miscue analysis classification is divided into three parts; Semantic Pragmatic Cueing System (the meaning-filled relationship of words, phrases, and sentences within a text), Syntactic Cueing system (the syntax within the text), and Graphophonic Cueing system (the phonological, orthographic and phonic within the text) (Goodman, Burke, \& Sherman, 1981). Those classifications give information about strategies that should be taught and used based on the problems found. For that reason, this present study used miscue analysis for pretest and posttest.

Questioning strategy is a strategy that can be used for students with reading problems. Questioning is an important element to facilitate students' learning as well as improving their motivations (Macalister, 2011). The most common strategy used in improving students' comprehension in reading classes is questioning any information that students have already read (Alvermann \& Phelphs, 2002). In this strategy, they are asked to create appropriate questions by using clues from the paragraph and also using their prior knowledge of the topic to predict what may be said in the paragraph (Manset-Williamson, Dunn, Hinshaw, \& Nelson, 2008). Effective questioning by both teachers and students is important, because being able to ask the right kinds questions appears may facilitate student learning. Teachers who can give a good example on how to ask proper questions while reading may help students to learn how to build interest with the text to become stronger readers. While the self-questioning strategy helps the students to be independent 
readers (El-Koumy, 2014). A study by Dunlap (2006) showed positive responds among the participants practicing self-questioning strategy, especially for those who had problems with second language acquisitions. Self-questioning strategy is used when students start asking themselves while they are learning and reading the texts, (Darling-Hammond, Austin, Cheung, \& Martin, 2003; Wicaksono \& Munir, 2014). Therefore, in this present study, a combination between a self-questioning strategy and teacher questioning strategy were used.

Questioning strategy can be conducted within three phases; pre, during and after reading phase. Questioning strategy in pre-reading activity is necessary as it may activate students' schemata about the text they are going to read. It provides background knowledge to make students understand the text better. The information from the text must be connected to what is already known to be easily comprehended. Readers who formulate questions while reading may anticipate what is to come in the text and look for information that can confirm or disconfirm from their predictions. Because these readers have questions, they can more easily check if the message they are constructing makes sense and if the text ideas are interrelated one to another. After-reading activities provide students with additional opportunities to practice what has been learned from the text and to help them link the textual information and their background knowledge.

Previous research conducted by Manset-Williamson et al. (2008) suggested that students with reading problems can have comprehension difficulties, and that self-questioning strategy significantly improve their ability to comprehend text supported by text-reader software. Another study suggested that there was a significant result of using teacher, self and a combination between both teacher and self-questioning strategies in increasing readers' performance (El-Koumy, 2014). In short, it can be said that the questioning strategy helps readers to improve their reading comprehension.

Previous studies such as El-Koumy (2014) and Samad, Jannah, and Fitriani (2017) used reading achievement pretest as an instrument to find out students' reading problem, while few studies used miscue analysis. Those previous studies did not use a combination between using miscue analysis, questioning strategy and giving an interview to the participants. However, using miscue analysis could be beneficial in a way that it could point out certain areas in which students needed to develop and determine what strategy should be taught. Therefore, this study tried to fill in this gap. The pretest and posttest would use miscue analysis as part of the assessment.

Journal on English as a Foreign Language, 9(2), 217-230

Copyright @ 2019 by JEFL, p-ISSN 2088-1657; e-ISSN 2502-6615 
The purpose of the present study was to examine the effectiveness of using questioning strategy to facilitate students' reading problem found through miscue analysis. The result of this study is expected to serve contribution to the teaching-learning process focusing on reading performance. Through questioning strategy, it contributes to reach better reading performance and raise students' reading motivation.

\section{METHOD}

\section{Subject}

There were two female students involved in this study. Both are students of National Chiayi University, Taiwan. They had roughly the same proficiency level as they were both in level C (the lowest English proficiency level based on the English exam in Taiwan). These two subjects were involved in the previous study of the researcher, which dealt with guessing the meaning and predicting strategy to improve their reading comprehension. The result showed that the strategies gave a positive impact on their reading performance, as there was a significant difference between pretest and posttest. In this present study, they unpredictably gained significant different result in pretest after having a 3month delay of treatment as for reason that the high-achieving student kept on using the strategy independently when she was reading in English. While another student, she rejected the strategy by never using the strategy anymore after the treatment.

\section{Research Instrument}

Miscue analysis and interview were used both in pre-test and post-test sessions. In the pre-test, the instruments were used to diagnose students' reading problem while in post-test they were used to measure students' achievement toward eight meetings of reading treatment. The texts that were used in miscue analysis were taken from a magazine under Goodman's criteria for selecting miscue analysis' materials. The texts were in the same length (less than 500 words) as the materials for miscue analysis.

For instructional materials, the texts were taken from a studio classroom. It is an English magazine specially designed for Taiwanese/Chinese students to learn English. Efforts were made in selecting the appropriate articles by considering the level of familiarity, length, and difficulty to the students. Articles with unfamiliar topics which consisted of less than 500 words were 
consistently used. The level of difficulty of each text was relatively the same. Therefore, it was chosen as the instructional material.

\section{Procedure}

In total, there were ten meetings with the students. It consisted of 2 meetings for tests (pre-test in the first meeting and post-test in the last meeting) and 8 meetings for reading treatment. The duration of each meeting was 90 minutes. There were two activities conducted during the pre and post-test. At first, the miscue test was conducted then it was followed by an interview. Their voice was fully recorded during those two activities. During the miscue test, the students were asked to read aloud a text and had to answer 10 multiple-choice questions consisted of vocabulary and comprehension questions. The vocabulary questions were used to identify students' low-level thinking process while the comprehension questions were used to identify students' high-level thinking process. The interview was conducted to find their difficulties during reading and the strategy they used. Some of the interview questions related to students' use of strategy. For example, "Do you think you are good at using this strategy? Why or why not", "Is the strategy helpful for you? Why or why not?", "Would you like to continue using the strategy while reading? Why or why not?" They were interviewed four times (pretest, posttest, test1 and test 2).

There were 8 treatment meetings which would be divided into two sections; the first four meetings would be teacher-generated questions while the rest would be students-generated questions. In the teacher questioning condition, the students needed to read the text only. In students-generated condition, the students were asked to generate questions before, during and after reading sessions. In student-generated questions, the students were freely asked to write any questions related to the text. The questions were in scaffolding condition based on Bloom's Taxonomy. The questions which were asked started from a lower level to the higher ones. It can be viewed as a sequence of progressive contextualization of the material (Anderson et al., 2001). At first, it could be started with the word, phrase or picture in the text to start a discussion on the topic. For example, when introducing a text about the desert, the teacher could start the discussion by asking questions such as, "What do you have in mind when you hear the word 'desert'?" "What could we find in a place called, desert?" In this phase, it's hoped that students might brainstorm any ideas related to the topic. Then, students were asked to explain their free associations. For example, "How did you come to that idea? and "Why do you think of Arabic countries when you hear the word 'desert'?" This kind of 
sharing might help to correct accessing of inappropriate background knowledge or schemata and provided students with an opportunity to correct misconceptions. Finally, this provided the basis for students' to understand the relation between the text and background information. In the final phase, students were asked to make free associations with the original concept, for example, "Do you have any other ideas about dessert?" Often, students would give some responses in this last phase which reflected their higher level of understanding.

In addition, there would be a reading comprehension test in every four meetings (in the $5^{\text {th }}$ and $9^{\text {th }}$ meeting). The materials (texts used in this test were on the same level of difficulties. They also had the same total words as the texts used in instructional materials. This test aimed to measure students' reading achievement after four weeks of treatment under the assumption that within four meetings, students could acquire the strategy taught.

\section{FINDINGS}

\section{Teacher Generated Questions}

In the teacher-generated question phase, S2 performed better than S1. In the first week of a tutorial, S1 got $60 \%$ while S2 got 20\% higher than S1. Therefore, S2 is called the High-Achieving Student (HAS) while S1 is LowAchieving Student (LAS). In week five, LAS showed her progress by having $20 \%$ higher score compared to her achievement in week two. In the same week, HAS showed lower progress by having only $10 \%$ higher score. This happened because from the pre-test result HAS had higher proficiency level than LAS, therefore in the final week HAS got a higher score than LAS. However, considering the higher progress made by LAS it was assumed that there would be another factor, which interfered their learning process.

\section{Students Generated Questions}

From the students' generated question phase result, it is more obvious that LAS showed more improvement than HAS. Table 1 and Table 2 show the progress of both students in each meeting. The same reason as the previous result could be applied in this phase. However, both LAS and HAS got lower scores in this phase. It was because this phase was more challenging as they needed to be an independent reader by asking themselves questions, which could help them to build their comprehension. Based on the daily performance observation and interview conducted on week five, HAS showed relatively 
more negative attitude and had a lower motivation to learn compared to LAS. HAS assumed that she had been a good reader herself so that she did not need any more strategies to apply while reading.

Table 1. Students' progress in teacher generated questions

\begin{tabular}{lcccc}
\hline & $\begin{array}{c}\text { Week 2 } \\
(\%)\end{array}$ & $\begin{array}{c}\text { Week 3 } \\
(\%)\end{array}$ & $\begin{array}{c}\text { Week 4 } \\
(\%)\end{array}$ & $\begin{array}{c}\text { Week 5 } \\
(\%)\end{array}$ \\
\hline Student 1 & 60 & 60 & 70 & 80 \\
Student 2 & 80 & 80 & 90 & 90 \\
\hline
\end{tabular}

Table 2. Students' progress in students' generated questions

\begin{tabular}{lcccc}
\hline & $\begin{array}{c}\text { Week 6 } \\
(\%)\end{array}$ & $\begin{array}{c}\text { Week } 7 \\
(\%)\end{array}$ & $\begin{array}{c}\text { Week } 8 \\
(\%)\end{array}$ & $\begin{array}{c}\text { Week } 9 \\
(\%)\end{array}$ \\
\hline Student 1 & 50 & 70 & 70 & 80 \\
Student 2 & 70 & 70 & 80 & 80 \\
\hline
\end{tabular}

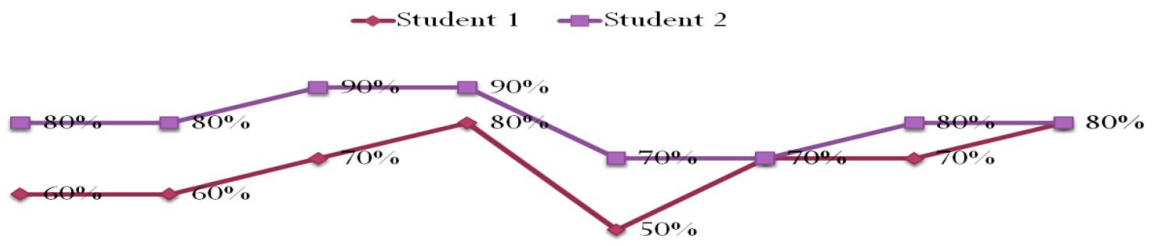

Week 2 Week 3 Week 4 Week 5 Week 6 Week 7 Week 8 Week 9

Figure 1. Students' progress in each meeting

It can be seen from Figure 1 that their overall performance from week 2 to week 4 showed improvement. Both students' performance declined in week 5. The reason for this was because it was the first time for them to have student's generated questions tutorial. It could be said that they were not ready yet to have the changes, from teacher-generated (teacher assisted) to studentsgenerated (independent). LAS's questions were more on vocabulary level (lower level) instead of higher-level questions, and HAS's questions were more

Journal on English as a Foreign Language, 9(2), 217-230

Copyright @ 2019 by JEFL, p-ISSN 2088-1657; e-ISSN 2502-6615 
on inferential questions and comprehension. As time went by, both of them could create higher-level questions rather than vocabulary level. At the end of the treatment, both students got the same final score, that was 80, but LAS showed more progress than HAS.

\section{Mini-test and Interview}

Table 3 shows each student's reading comprehension test results in teacher's generated questions (test1) and students generated questions (test2). LAS's score improved 20 from 70 to 90, while HAS did not show any improvement. This test result is consistent with students' progress in each meeting in which LAS showed more progress than HAS. This happened because HAS rejected the strategy taught and showed a more negative attitude toward the strategy.

Table 3. Students' mini test result

\begin{tabular}{lcc}
\hline & Test 1 & Test 2 \\
\hline LAS & 70 & 90 \\
HAS & 90 & 90 \\
\hline
\end{tabular}

In daily reading treatment, HAS often came late and did not pay much attention during the treatment. She sometimes seemed to be reluctant to have the treatment. In the interview section, when she was asked "will you use questioning strategy when you are reading a text?" then she said, "not really, because I think I can comprehend the text without making questions". Her answer showed her negative intention toward the strategy, therefore it influenced her reading performance.

\section{Pretest and Posttest}

From the pretest, the result showed in Table 4 and 5, it can be concluded that LAS made more miscues than HAS. After having an interview with both students, it was found that LAS did not apply the strategies while she was reading during the time delay while HAS did another way around. She kept using the strategies and read many English articles. HAS also had a higher motivation than LAS considering their usages of English during the delay. 
Table 4. LAS pretest and posttest result

\begin{tabular}{lll}
\hline LAS & Pretest & Posttest \\
\hline Total miscue & $34 \%$ & $25 \%$ \\
Reading comprehension & 50 & 80 \\
Interview & Stop using strategy & positive attitude \\
\hline
\end{tabular}

Posttest result indicated that HAS still got a higher score than LAS. However, this did not mean that the strategy worked better in HAS instead of LAS. The score difference that they made in reading comprehension between pretest and posttest needed to be observed as HAS only showed 10 scores increased while LAS showed a more significant difference for having 30 scores increased. The same condition also applied to the result of miscue analysis. HAS showed less progress as she could just reduce her miscues by $4 \%$. On the other hand, LAS could reduce her miscues by $9 \%$.

Table 5. HAS pretest and posttest result

\begin{tabular}{lll}
\hline HAS & Pretest & Posttest \\
\hline Total miscue & $23 \%$ & $19 \%$ \\
Reading comprehension & 80 & 90 \\
Interview & Continue using strategy & negative attitude \\
\hline
\end{tabular}

The result of the interview gave some data related to the reasons underlying the students' reading performance. It was found that LAS started with low motivation for learning English, but as the tutorial went on, she could raise her motivation along with her self-esteem. The other way around happened to HAS as her motivation was getting lower during the tutorial.

\section{DISCUSSION}

The findings proved that the use of questioning strategy was effective to increase students' reading comprehension. Both students showed an increased score at the end of the treatment. However, the scores both students' achieved showed that the strategy worked better in Low Achieving Student (LAS) than in High Achieving Student (HAS). From the post-test, LAS gained more points compared to HAS. LAS could outperform HAS although her point was way lower than HAS in the pretest. This could happen because both students had a different level of motivations along with the treatments. LAS showed higher motivation as well as more positive attitudes toward the strategies than HAS. It was an interesting finding as it was assumed that HAS should have performed 
better than LAS. This reflected the role of motivation that could influence reading performance.

LAS began with the low motivation of reading English articles. She never read any English articles except in her English class, which she had in the last six months. Moreover, she also had low self-efficacy for herself as a reader. She saw herself as a poor English reader. As the reading treatment went on, she started to gain her English confidence and got a higher motivation to learn the strategy. It was proven by the improvement of her reading performance as she could answer and create more and more questions. She could accept the strategy as she mentioned that the strategy was helpful for her and helped her to be more focus on the points she would like to know. Moreover, she also made significant progress in all test and her daily performance. The strategy instruction could motivate her and help her to gain confidence in reading. She also expressed her willingness to use the strategy if she wanted to read.

On the other hand, HAS started the study with the high motivation of English reading. She often read English magazine or any other English articles. She also saw herself as a good reader, meaning that she had a high self-efficacy of English reading. It was expected that HAS should have had more progress than LAS. Unfortunately, her motivation decreased and she did not make much progress during the treatment though she always got a better score than LAS. The strategy instruction did not helpful for her as she said that she could still comprehend the text without using this strategy. Based on the interviews, she might have perceived the strategy instruction as a less-effective strategy for her. She gave some indications of this point that questioning strategy was not needed to comprehend the text because there would be some comprehension questions followed after each text. She did not need to add more questions to be answered. Moreover, as she was involved in our previous study, she thought the strategies taught before (predicting and guessing the meaning from context) were more effective than questioning strategy. She would prefer to use the former ones when she wanted to read. This may lead her to build a negative response toward this strategy instruction and decrease her motivation toward reading.

\section{CONCLUSION}

This study concludes that, first, the strategy instruction (questioning strategy) could increase students' reading comprehension. Second, motivational factors affect the effectiveness of the use of the strategy. This study shows how high-motivated students (HAS) could perform better than low motivated 
students (LAS). Third, each reading strategy works differently in each reader. LAS might perform better when they use their preferred strategy than other strategies were forced on them through instruction. Moreover, this could affect their motivation toward strategy instruction and influence their reading performance. As motivation affect students' reading performance, therefore, this study suggests that raising students' motivation in the teaching process is necessary to reach better reading performance. Giving motivations to the students can be carried out all the way along with teaching reading strategies. Another pedagogical implication is that teacher could not force students to use certain strategies, and better to allow them using their preferred strategy. Pushing students to use a certain strategy may demotivate students' interest to learn. Letting students choose their preference may boost their motivation so that they could comprehend more.

Some limitations still could be found in this study. First, there was time limitation and the number of participants. The time to conduct this study was only eight meetings while it just involved two participants. For future research, it may involve a longer time and more participants to see the achievement clearer. Second, it was a language problem. Since the subjects' English language proficiency was not really good, some communication problems might happen during the tutorial times. Both subjects and researchers might fail to communicate their intention toward each other well. Furthermore, both subjects and researchers shared different native languages. It might be an easier task if both sides had the same native language.

\section{REFERENCES}

Alderson, J. C. (2000). Success in English Teaching. New York: Oxford University Press.

Alfermann, D. E., \& Phelphs, S.F. (2002). Content reading and literacy: Succeeding in today's diverse classrooms (3rd ed.). Boston: Allyn and Bacon.

Anderson, L. W, Krathwohl, D. R., Airasian, P. W., Cruikshank, K. A., Mayer, R. E., Pintrich, P. R., Raths, J., \& Wittrock, M. C. (Eds.). (2001). A taxonomy for learning, teaching and assessing: A revision of Bloom's Taxonomy of educational objectives. New York: Addison Wesley Longman, Inc.

Anisah, N. Fitriati, S. W., \& Rukmini, D. (2019). Teachers' questioning strategies to scaffold students' learning in reading. English Education Journal, 9(1), 128-143.

Darling-Hammond, L., Austin, K., Cheung, M., \& Martin, D. (2003). Thinking about thinking: Metacognition. London: Stanford University Press

Journal on English as a Foreign Language, 9(2), 217-230

Copyright @ 2019 by JEFL, p-ISSN 2088-1657; e-ISSN 2502-6615 
Dunlap, J. A. (2006) The effects of self-questioning on comprehension of expository text and development of content writing with second-grade students, ProQuest Dissertations and Theses. Wichita State University. Available at: http://proxy.libraries.smu.edu/login?url=https://search.proquest.com/doc view $\beta 04976781$ ? accountid $=6667$.

Edwards, S., \& Bowman, M. A. (1996). Promoting student learning through questioning: A study of classroom questions. Journal on Excellence in College Teaching, 7(2), 3-24.

El-Koumy, A. S. (2014). Effects of three questioning strategies on EFL reading comprehension. SSRN Electronic Journal. doi: 10.2139/ssrn.2364867.

Goodman, Y. M., Burke, C., \& Sherman, B. (1981). Reading strategies: Focus on comprehension. The English Journal on JSTOR, 70(7), 89. doi: $10.2307 / 817495$.

Goodman, Y. M., Watson, J. D., \& Burke, C. L. (1996). Reading strategies: Focus on comprehension. New York: Richard C. Owen Publishers.

Kazemi, M., Hosseini, M., \& Kohandani, M. (2013). Strategic Reading Instruction in EFL Contexts. Theory and Practice in Language Studies, 3(12), 2333-2342.

Klinger, J. K., Vaughn, S., \& Boardman, A. (2007). Teaching reading comprehension to students with learning difficulties. New York: The Guildford Press.

Long, P. (1987). Reading Miscue Inventory: Alternative Procedures by Y. Goodman, D. Watson and C. Burke Published by Richard C. Owen. New York, 1987, Australasian Journal of Special Education, 3(11), 43-44. doi: $10.1017 / s 1030011200021825$.

Macalister, J. (2011). Today's teaching, tomorrow's text: Exploring the teaching of reading. ELT Journal, 64(2), 161-169. doi: 10.1093/elt/ccq023.

Manset-Williamson, G., Dunn, M., Hinshaw, R. E., \& Nelson, J. M. (2008). The impact of self-questioning strategy use on the text-reader assisted comprehension of students with reading disabilities. International Journal of Special Education, 23(1), 123-135.

Paran, A. (1996). Reading in EFL: Facts and fictions. ELT Journal, 50(1), 25-34. doi: 10.1093/elt 50.1 .25 .

Phillips, D. (2003). Longman preparation course for the TOEFL test. London: Longman.

Samad, I. A., Jannah, M., \& Fitriani, S. S. (2017). EFL students' strategies dealing with common difficulties in TOEFL reading comprehension section. International Journal of Language Education, 1(1), 29-36. doi: 10.26858/ijole.v1i1.2869.

Whitmore, K., \& Crowell, C. G. (1994). What makes a question good is. New

Journal on English as a Foreign Language, 9(2), 217-230

Copyright @ 2019 by JEFL, p-ISSN 2088-1657; e-ISSN 2502-6615 
Advocate, (pp. 45-57). Available at: http://search.proquest.com/docview/62818658?accountid=12339.

Wicaksono, R. T., \& Munir, A. (2014). Applicability of self-questioning strategy in comprehending narrative text. Retain, 1(1), 216.

\section{Author's Brief CV}

Ike Irawati is an English teaching lecturer at Universitas Krisnadwipayana, Bekasi, Jawa Barat. She finished her study of English Literature from Universitas Gadjah Mada, Yogyakarta and gained her Master of Arts from National Chiayi University, Taiwan majoring in English Teaching. She is interested in researches on TEFL, mainly about vocabulary learning and reading strategy. 